\title{
Muralismo
}

Sección "Ver y Leer" que presenta una serie de reseñas sobre diversas fuentes de información como: libros, revistas, videos didácticos, murales, sitios virtuales entre otro material que aborde temas relativos a la cultura, historia, arte y educación, vinculándolos a la formación humanista del profesor.

\section{en Aguascalientes}

Luciano Ramírez Hurtado

Tstimado profesor universitario, ¿sabías que Osvaldo Barra Cunningham (n. Concepción, Chile, 4 de febrero de 1922- m. México, D.F., 19 de mayo de 1999) es el principal exponente del muralismo en Aguascalientes? Él fue discípulo de Diego Rivera y comenzó en la sexta década del siglo XX una historia de relaciones profesionales con el más importante mecenas del arte público: el Estado. En 1961 pintó el mural "Aguascalientes en la Historia", en el segundo patio del Palacio de Gobierno en el cual relata la historia de nuestra entidad desde la época de la Conquista hasta la etapa postrevolucionaria, a la vez que critica instituciones como la iglesia católica, el sistema de justicia, la prensa escrita y la viticultura. En 1962 realizó "La Feria de San Marcos" en la planta alta del primer patio, mural en el que además de retratar la alegría de las fiestas de abril critica la desigualdad social de su tiempo.

Si te interesa conocer un poco más acerca de ambas manifestaciones pictóricas, apegadas a la escuela mexicana de pintura, te recomiendo pasees in situ por el Palacio de Gobierno y observes los vídeos "Aguascalientes en la Historia, el polémico mural de Palacio de Gobierno", y "Mural de la Feria de San Marcos. Alegorías y retratos sociales de una época", con base en una investigación histórica e iconográfica de mi autoría. Los puedes encontrar en la librería universitaria o bien en el Departamento de Videoproducción, en el edificio 16.

Considero que este tipo de material didáctico es sumamente útil y puede ser de interés en carreras como Historia (materias como Historia del Arte Mexicano, Historia Regional, México Contemporáneo), Ciencias del Arte y Gestión Cultural (Iconografía e Iconología), Letras Hispánicas (Historia del Arte II) y en general todos los programas de licenciatura y posgrado que en su currícula llevan materias relacionadas con la historia del arte y el análisis de imágenes histórico-artísticas.

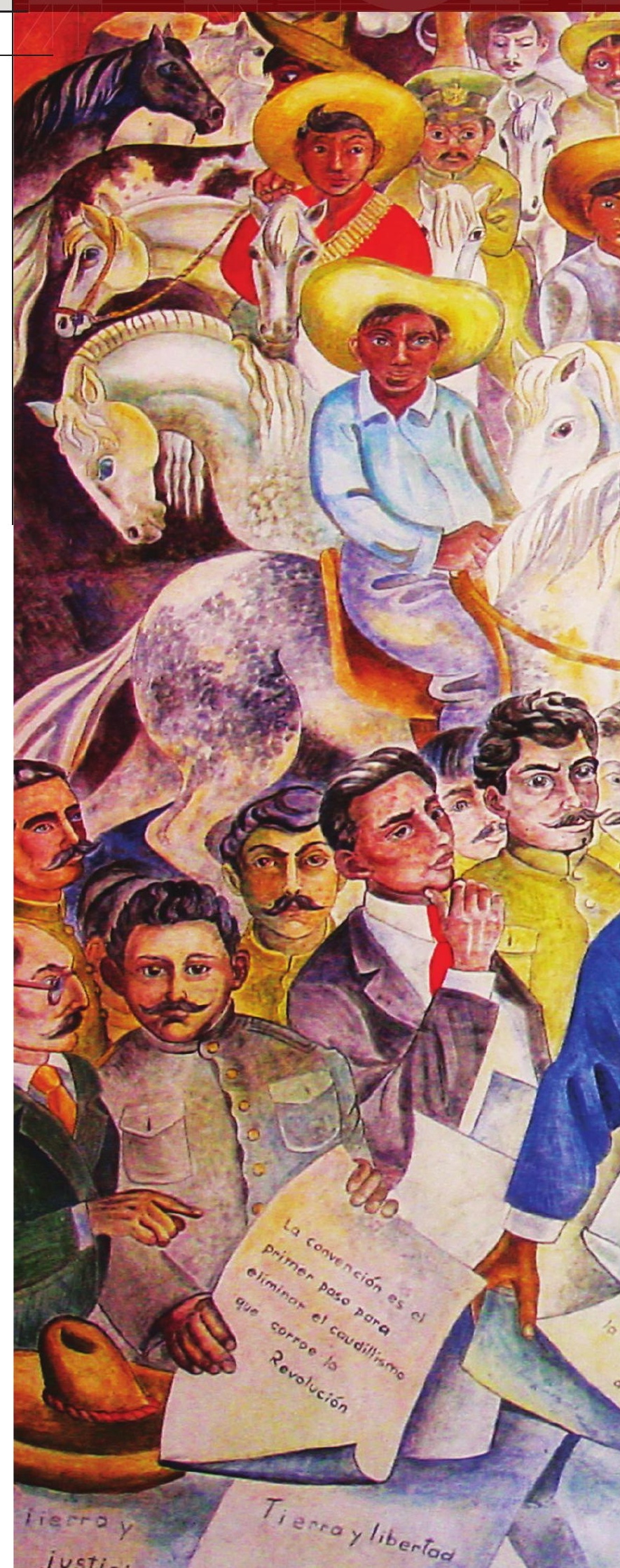




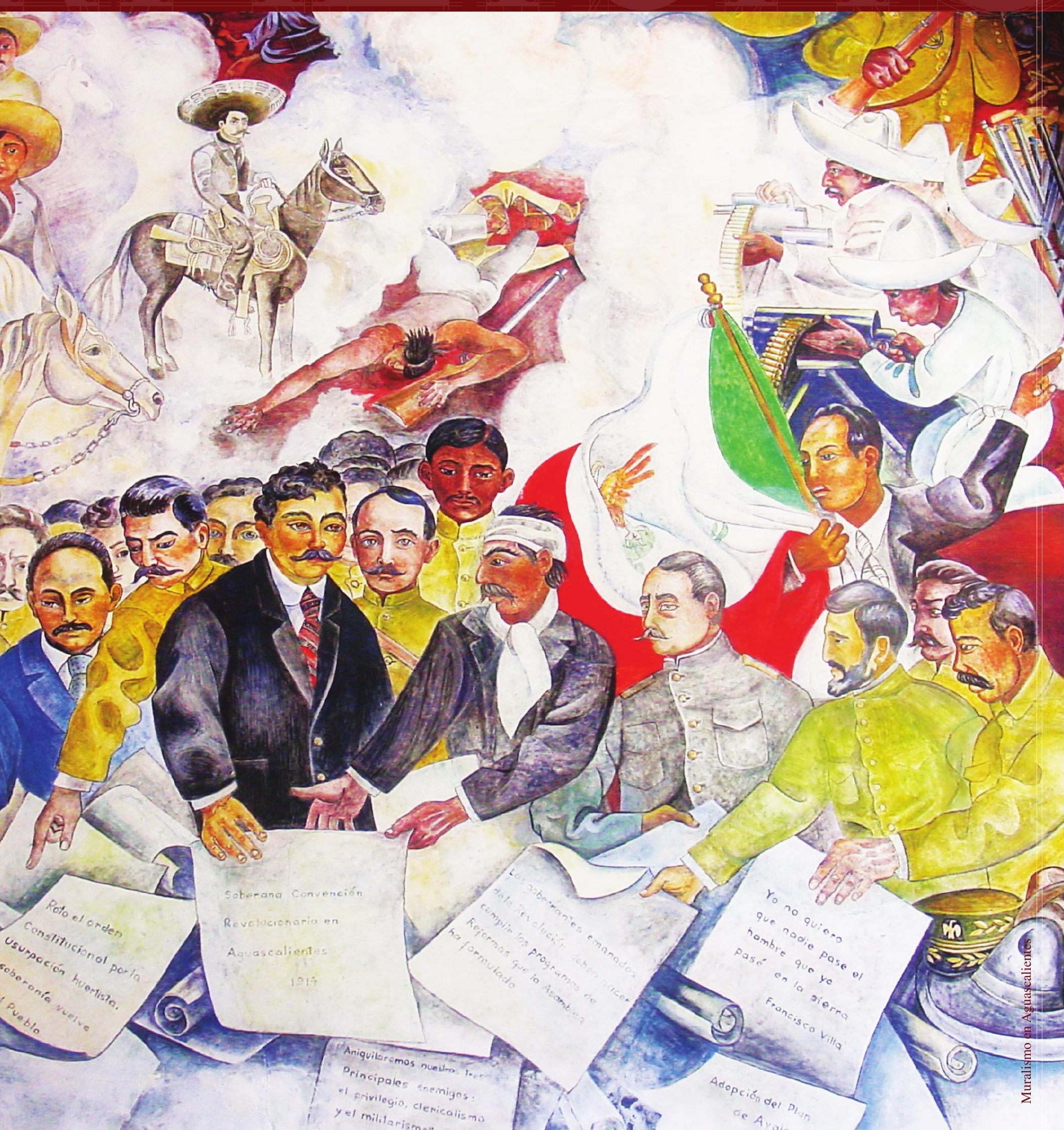

